\title{
PENGEMBANGAN INSTRUMEN KEMAMPUAN INKUIRI ILMIAH SISWA SMP
}

\author{
Nurilah Hanum \\ SMP Negeri 12 Kota Tangerang \\ Selatan
}

\begin{abstract}
The ability of scientific inquiry junior high school students is the ability or skill of a junior high school students in mastering a skill and is used to perform a variety of tasks from the work done by establishing the curiosity of students. Step-by-step preparation and instrument development is done according to the steps in the preparation and development of instruments Djaali and Pudji Muljono. How to validate to the validity of the content using the lattice by way of consultation professional (expert and panelist), the results of validation (experts and panelists) quantitatively by calculating the value of the CVR (content validity ratio), to validate the construct validity score of grains by factor analysis (Lisrell) and estimating the reliability of the instrument. Results of the validation expert (panelists) quantitatively by calculating the value of the CVR turns of 57 questions, the index CVR for the content validation entirely appropriate and very appropriate, validation results with 49 experts and panelists. Of the 57 items when analyzed with CFA, there are 54 items that valid means there is no difference between unidimensional theoretical models with empirical models. In the first dimension which consists of 9 matter, entirely valid. In the second dimension composed of about 8, 6, and 2 valid about the other matter dropped. In the third dimension which consists of 10 questions, 9 valid question and one other matter dropped. In the fourth dimension which consists of 10 questions, entirely valid. At 5 dimensions consisting of 10 questions, entirely valid. In the sixth dimension which consists of 10 questions, entirely valid. Reliability coefficient calculation results of phase one $r=0,9958$ while the results of the reliability coefficient calculation stage two $r=0,996$ I with the reliability coefficient $>0,70$, then the test has a high level of reliability. Of the 54 items analyzed by the CFA after the second trial, there are 28 items that valid means there is no difference between unidimensional theoretical models with empirical models. In the first dimension consists of 9 questions, 4 questions are valid, and 5 matter dropped. In the second dimension consists of 6 questions entirely dropped. In the third dimension which consists of 9 questions, 2 questions are valid and 7 other matter dropped. In the fourth dimension which consists of 10 questions, 8 questions are valid, and 2 other matter dropped. In the fifth dimension which consists of 10 questions, 9 valid question, and one question was dropped. In the sixth dimension consisting of 10 questions, 5 questions are valid, and 5 matter dropped. Reliability coefficient calculation results of the second trial $r=0,9825$ with a reliability coefficient $>0,70$, then the test has a high level of reliability.
\end{abstract}

\section{Keywords}

instrument development, the ability of scientific inquiry, junior high school students 
item yang valid artinya tidak terdapat perbedaan antara model teoretis unidimensional dengan model empiris. Pada dimensi I yang terdiri dari 9 soal, seluruhnya valid. Pada dimensi 2 yang terdiri dari 8 soal, 6 soal valid dan 2 soal lainnya didrop. Pada dimensi 3 yang terdiri dari 10 soal, 9 soal valid dan I soal lainnya didrop. Pada dimensi 4 yang terdiri dari 10 soal, seluruhnya valid. Pada dimensi 5 yang terdiri dari 10 soal, seluruhnya valid. Pada dimensi 6 yang terdiri dari 10 soal, seluruhnya valid. Hasil penghitungan koefisien reliabilitas tahap satu $r=0,9958$ sedangkan hasil penghitungan koefisien reliabilitas tahap dua $r=0,996 \mathrm{I}$ dengan koefisien reliabilitas $>0,70$, maka tes memiliki tingkat reliabilitas yang tinggi.

Dari 54 item setelah dianalisis dengan CFA pada uji coba kedua, ada 28 item yang valid artinya tidak terdapat perbedaan antara model teoretis unidimensional dengan model empiris. Pada dimensi I yang terdiri dari 9 soal, 4 soal valid, dan 5 soal didrop. Pada dimensi 2 yang terdiri dari 6 soal seluruhnya didrop. Pada dimensi 3 yang terdiri dari 9 soal, 2 soal valid dan 7 soal lainnya didrop. Pada dimensi 4 yang terdiri dari 10 soal, 8 soal valid, dan 2 soal didrop. Pada dimensi 5 yang terdiri dari 10 soal, 9 soal valid, dan I soal didrop. Pada dimensi 6 yang terdiri dari 10 soal, 5 soal valid, dan 5 soal didrop. Hasil penghitungan koefisien reliabilitas pada uji coba kedua $r=$ 0,9825 dengan koefisien reliabilitas $>0,70$, maka tes memiliki tingkat reliabilitas yang tinggi.

Kata Kunci

Pengembangan instrumen, kemampuan inkuiri ilmiah, siswa SMP

\section{Pendahuluan}

Rasa ingin tahu merupakan salah satu sifat dasar yang dimiliki manusia. Sifat tersebut akan mendorong manusia bertanya untuk mendapatkan pengetahuan. Rasa ingin tahu dapat mendorong seorang untuk berpikir kreatif. Kreativitas adalah modal yang harus dimiliki setiap siswa agar mampu mengikuti perkembangan zaman serta mencari solusi atas masalah yang dihadapinya. Oleh karenanya, pendidikan harus dapat ditujukan untuk mendorong siswa lebih kreatif. Metode ilmiah adalah kerangka landasan bagi terciptanya pengetahuan ilmiah yang mendorong siswa mengembangkan rasa ingin tahu yang lebih besar. Pengetahuan ilmiah diperoleh dari kemampuan berpikir. Setiap jenjang pendidikan diharapkan menerapkan discovery learning (belajar penemuan) yang merupakan salah satu dari delapan tahapan inkuiri, membangun pengetahuan secara induktif dari pengalaman-pengalaman.

Pembelajaran IPA SMP/MTs sebaiknya dilaksanakan secara inkuiri ilmiah untuk menumbuhkan kemampuan berpikir. Keterampilan berpikir yang dikembangkan sebaiknya sudah menjangkau keterampilan berpikir tingkat tinggi atau dikenal dengan istilah "Higher Order Thinking Skill" (HOTS), yang jika ditinjau dari taksonomi baru Marzano dan Kendall berada pada level 3 Analisis (Analysis) yang terdiri dari mencocokkan (Matching), mengelompokkan (Classifying), analisis kesalahan (Analyzing Errors), generalisasi (Generalizing), dan menspesifikkan (Specifying), serta level 4 Penggunaan Pengetahuan (Knowledge Utilization) yang terdiri dari membuat keputusan (Decision Making), menyelesaikan masalah (Problem Solving), melakukan percobaan (Experimenting), dan penyelidikan (Investigating). Badan Standar Nasional Pendidikan (BSNP)/Peraturan Pemerintah Nomor 19 Tahun 2005, menetapkan bahwa inkuiri ilmiah (scientific inquiry) sebagai standar proses dalam pelaksanaan pembelajaran IPA diberbagai tingkat pendidikan. Pembelajaran secara inkuiri bertujuan untuk menumbuh kembangkan kemampuan berpikir, bekerja dan bersikap ilmiah serta mengkomunikasikannya sebagai aspek penting dalam kecakapan hidup. Inkuiri adalah proses mendefinisikan dan menginvestigasi permasalahanpermasalahan, merumuskan hipotesis, 
merencanakan investigasi, mengumpulkan data, dan mengemukakan kesimpulan tentang permasalahan-permasalahan yang dihadapi peserta didik. Peneliti ingin mengkonsentrasikan penelitiannya pada pengembangan Instrumen Kemampuan Inkuiri Ilmiah (scientific atau disciplined inquiry) siswa SMP. Belum adanya standarisasi instrumen kemampuan inkuiri ilmiah juga menjadi pertimbangan penulis mengembangkan instrumen ini.

Untuk mendapatkan instrumen yang berkualitas dibutuhkan langkah-langkah penyusunan instrumen. "Kualitas instrumen pengumpulan data berkaitan dengan validitas dan reliabilitas instrumen." Secara lebih rinci, Djaali dan Pudji Muljono menjelaskan langkah-langkah penyusunan dan pengembangan instrumen, yaitu:

I. Berdasarkan sintesa teori-teori yang dikaji tentang suatu konsep dari variabel yang hendak diukur, kemudian dirumuskan konstruk dari variabel tersebut. Konstruk pada dasarnya adalah bangun pengertian dari suatu konsep yang dirumuskan oleh peneliti.

2. Berdasarkan konstruk dikembangkan dimensi dan indikator variabel sesuai dengan rumusan konstruk variabel

3. Membuat kisi-kisi instrumen dalam bentuk tabel spesifikasi yang memuat dimensi, indikator, nomor butir, dan jumlah butir untuk setiap dimensi dan indikator

4. Menetapkan besaran atau parameter yang bergerak dalam suatu rentangan kontinum dari suatu kutub ke kutub lain yang berlawanan, misalnya dari rendah ke tinggi, dari negatif ke positif, dari otoriter ke demokratik, dari dependen ke independen, dan sebagainya.

5. Menulis butir-butir instrumen baik dalam bentuk pertanyaan maupun pernyataan. Biasanya butir instrumen digolongkan menjadi dua kelompok, yaitu: kelompok pernyataan atau pertanyaan positif dan kelompok pernyataan atau pertanyaan negatif

6. Butir yang ditulis divalidasi secara teoretik dan empirik

7. Validasi pertama, yaitu: validasi teoretik ditempuh melalui pemeriksaan pakar atau panelis yang menilai seberapa jauh ketepatan dimensi sebagai jabaran dari konstruk, indikator sebagai jabaran dimensi dan butir sebagai jabaran indikator

8. Revisi instrumen berdasarkan saran pakar atau penilaian panelis

9. Setelah konsep instrumen dianggap valid secara teoretik dilanjutkan penggandaan instrumen secara terbatas untuk keperluan uji coba

10. Validasi kedua adalah uji coba instrumen di lapangan yang merupakan bagian dari proses validasi empirik. Instrumen diberikan kepada sejumlah responden sebagai sampel yang mempunyai karakteritik sama dengan populasi yang ingin diukur. Jawaban responden adalah data empiris yang kemudian dianalisis untuk menguji validitas empiris atau validitas kriteria dari instrumen yang dikembangkan.

II. Pengujian validitas krtieria atau validitas empiris dapat dilakukan dengan menggunakan kriteria internal maupun kriteria eksternal

12. Berdasarkan kriteria tersebut dapat diperoleh butir mana yang valid dan butir yang tidak valid

13. Untuk validitas internal atau kriteria internal, berdasarkan hasil analisis butir yang tidak valid dikeluarkan atau direvisi untuk diujicobakan kembali sehingga menghasilkan semua butir valid.

14. Menghitung koefisien reliabilitas yang memiliki rentangan $0-\mathrm{I}$, makin tinggi koefisien reliabilitas instrumen berarti makin baik kualitas instrumen

15. Merakit semua butir yang telah dibuat menjadi instrumen yang final.

Penelitian ini merupakan penelitian pengembangan instrumen kemampuan inkuiri ilmiah siswa SMP pada mata pelajaran Biologi, yang diharapkan dapat menjadi instrumen baku untuk pembelajaran IPA/Biologi di SMP/MTs, kelas VIII pada kurikulum 2006 (KTSP) dan dapat digunakan sebagai instrumen baku pada kurikulum 20I3 IPA terpadu untuk ujian tingkat kompetensi tingkat 4 (akhir kelas VIII) dan tingkat 4-A (akhir kelas IX) dapat juga digunakan untuk ujian mutu tingkat kompetensi (UMTK). Instrumen kemampuan inkuiri ilmiah ini dikembangkan dengan tujuan akhir, yaitu: dihasilkannya tes baku kemampuan berpikir ilmiah, kemampuan bekerja ilmiah, 
kemampuan bersikap ilmiah, dan kemampuan berkomunikasi ilmiah. Tes baku yang dihasilkan adalah butir-butir soal yang menuntut penalaran lebih tinggi, yang harus mampu mengukur kemampuan berpikir kritis dan harus mampu mengukur keterampilan pemecahan masalah.

\section{Metodologi Penelitian}

Cara memvalidasi dan mengestimasi reliabilitas instrumen, validitas konstruk mengacu pada sejauh mana suatu instrumen mengukur konsep dari suatu teori, yaitu: yang menjadi dasar penyusunan instrumen. Untuk menguji validitas konstruk, dapat digunakan pendapat para ahli (expert judgement). Penilaian rater terhadap instrument/judgement professional terdiri dari empat pakar, seorang pakar inkuiri dari FPMIPA, Sekolah Pascasarjana Universitas Pendidikan Indonesia (UPI) Bandung, seorang pakar Biologi FPMIPA, Universitas Pendidikan Indonesia (UPI) Bandung, seorang pakar inkuiri dari FMIPA Universitas Islam Negeri (UIN) Syarif Hidayatullah Jakarta, dan seorang pakar penelitian dan evaluasi pendidikan Pascasarjana Universitas Negeri Jakarta (UNJ). Panel terdiri dari sejumlah ahli (45 orang guru IPA/Biologi di lingkungan gugus $0 \mathrm{I}$ Pondok Aren, Kota Tangerang Selatan, Bekasi, Serang, Provinsi Banten, Jambi, dan Kalimantan Barat, yang tergabung dalam MGMP IPA) untuk menilai relevansi butir yang telah dibuat dengan indikator dari konsep variabel yang akan diukur.

Prosedur validasi konstruk juga dapat ditempuh melalui teknik analisis faktor (Lisrell). Masukan panel digunakan untuk menghitung CVR (rasio validitas konten) untuk setiap item dalam instrumen pengukuran. Menghitung nilai CVR adalah:

$$
\mathrm{CVR}=\left(\frac{\mathrm{Mp}-\frac{\mathrm{M}}{2}}{\frac{\mathrm{M}}{2}}\right)=\frac{2 \mathrm{Mp}}{\mathrm{M}}
$$

Keterangan:

$M_{p} \quad$ = jumlah responden yang menyatakan $\mathrm{Ya}$

$M \quad=$ total responden yang memvalidasi

\section{Kategori hasil perhitungan CVR}

Hasil perhitungan CVR adalah berupa rasio angka 0-I. Angka tersebut dapat dikategorikan sebagai berikut:

Tabel I. Indeks CVR untuk Validasi Isi

\begin{tabular}{|c|c|}
\hline Indeks CVR & Keterangan \\
\hline $0-0,33$ & Tidak sesuai \\
\hline $0,34-0,67$ & Sesuai \\
\hline $0,68-1$ & Sangat sesuai \\
\hline
\end{tabular}

Butir telah memenuhi validitas isi jika terdapat kecocokan di antara validator di atas 0,50. Untuk mengukur CVR, sejumlah ahli (panel) diminta untuk memeriksa setiap item pada instrumen pengukuran. Penyekoran terdiri dari tiga alternatif, yaitu: item tertentu adalah relevan, kurang relevan, atau tidak relevan dengan domain yang diukur atau esensial, tidak esensial, dan tidak relevan. Penyekoran ini dilakukan terhadap semua item. Nilai reliabilitas ini merupakan kuadrat dari factor loading tiap item yang merupakan estimasi komunalitas terhadap variabel. Komunalitas (communality) adalah persentase varian item yang dapat menjelaskan konstruk ukur. Dengan melakukan analisis faktor konfirmatori melalui program bantu analisis SEM (misalnya AMOS atau LISREL) besarnya koefisien ini secara otomatis akan ditampilkan. Koefisien Reliabilitas Item mengungkap seberapa jauh sebuah item dapat menggambarkan sebuah konstruk laten. Karena variabel error tidak hanya memuat error pengukuran saja akan tetapi error yang lain, maka koefisien reliabilitas item mengestimasi pada batas bawah reliabilitas murni. Uji reliabilitas menunjukkan sejauh mana suatu alat ukur yang dapat memberikan hasil yang relatif sama apabila dilakukan pengukuran kembali pada obyek yang sama. Reliabilitas dihitung dengan formula Variance Extract dan Construct Reliability dengan rumus sebagai berikut:

Contruct Reliability $=$

$\left(\sum \text { Standardized Loading }\right)^{2}$

$\left.\overline{\left(\sum S t a n d a r d i z e d ~ L o a d i n g\right.}\right)^{2}+\left(\sum\right.$ Measurement error $)$

Variance Extract $=$

$\sum$ Standardized Loading

$=\frac{\sum \text { Standardized Loading }{ }^{2}+\sum \text { Measurement error }}{\sum \text { Sure }}$ 
Makin besar nilai ini, menunjukkan bahwa indikator-indikator penyusun bagi suatu peubah laten merupakan indikator-indikator yang handal dalam mengukur peubah laten tersebut. Nilai kehandalan konstruk yang disarankan adalah lebih besar dari 0,7. Sedangkan ukuran kelayakan variance extracted yang disarankan adalah lebih besar dari 0,5. Pengambilan sampel dilaksanakan di SMP Negeri 12 Kota Tangerang Selatan, dengan jumlah responden 316 siswa, responden seluruhnya adalah siswa kelas IX. Tahapan pengembangan instrumen kemampuan inkuiri ilmiah yang peneliti gunakan dapat dilihat pada Tabel 2 berikut ini:

Tabel 2. Tahapan Pengembangan Instrumen

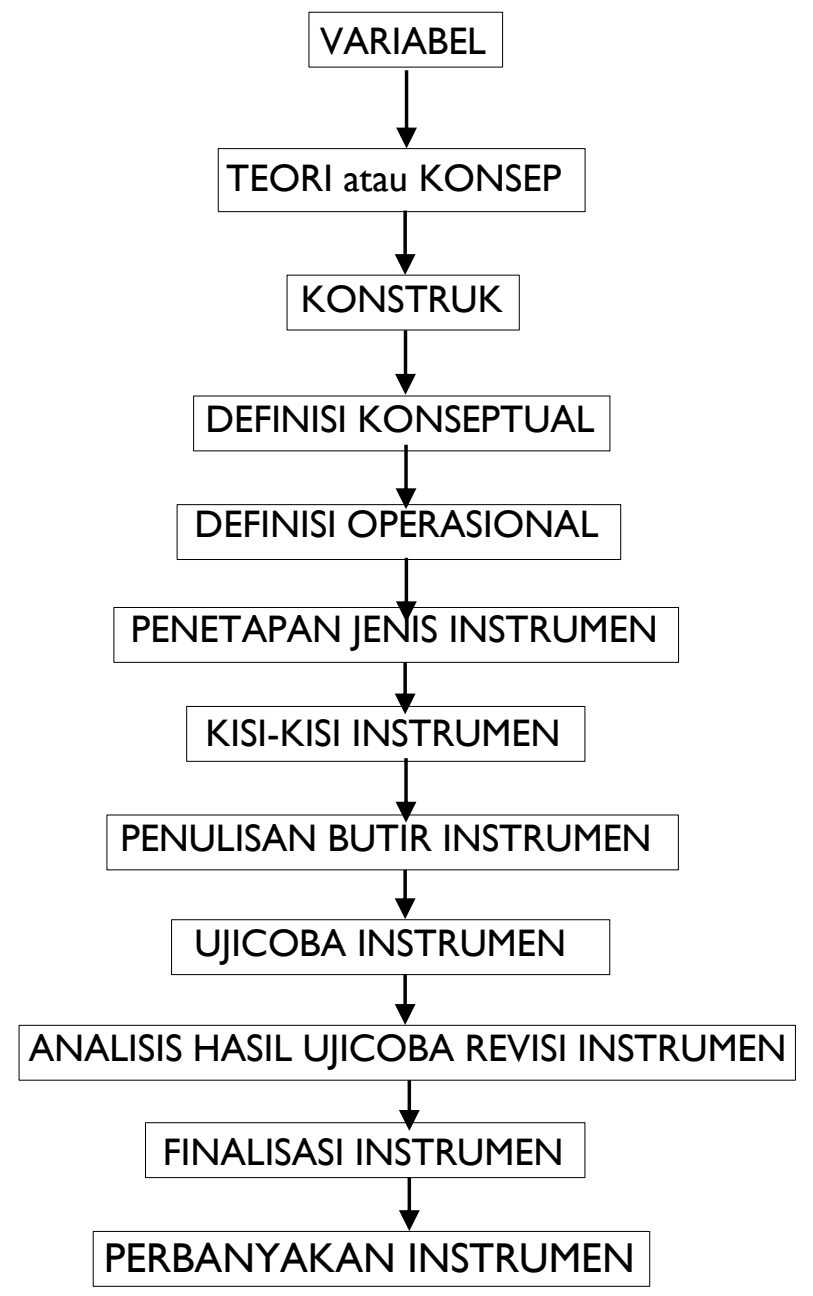

\section{Hasil atau temuan Penelitian dan Pembahasan Hasil Penelitian}

Penelitian ini merupakan penelitian pengembangan instrumen kemampuan inkuiri ilmiah siswa SMP pada mata pelajaran Biologi, hasil validitas teoretik berdasarkan telaah pakar adalah sebagai berikut:

I. Seorang pakar inkuiri dari UPI menyarankan bahwa indikator dan butir soal sesuai, hanya perlu perbaikan pada beberapa butir soal untuk penyempurnaan, ada soal-soal yang konseptual sehingga soal tersebut dibebani konsep, ada beberapa soal yang mengukur kemampuan interpretasi, soal yang menarik kesimpulan (conclusion) atau juga termasuk interpretasi (generalizing) merupakan bagian dari menarik kesimpulan, dapat dianggap (generalizing) apabila ditinjau dari aspek yang lebih kompleks, soal yang menggunakan gambar harus jelas gambarnya agar tidak menimbulkan miskonsepsi, pada soal yang menggunakan beberapa pernyataan, ada pernyataan yang harus diganti dengan kalimat lain, pada beberapa soal, pilihan dibuat lebih netral, tidak terlalu jelas, cenderung menggiring pada jawaban, untuk soal konsep ada yang terlalu sulit di luar jangkauan kemampuan siswa SMP.

2. Seorang pakar Biologi dari UPI menyarankan walaupun instrumen belum menggambarkan /mengukur inkuiri ilmiah, Proses HOTS masih rendah/tidak berkembang dengan soal demikian, gambar-gambar harus diperjelas, tabel-tabel diperbaiki supaya tidak membingungkan penafsiran, untuk menilai instrumen perlu ada kunci jawaban yang tepat disertai rubriknya, soal inkuiri, jawaban diperoleh melalui kegiatan siswa, bukan hasil mengingat, tetapi pada dasarnya indikator dan soal sudah sesuai, hanya perlu beberapa perbaikan.

3. Seorang pakar inkuiri dari UIN Syarif Hidayatullah Jakarta, menyarankan soal pada dasarnya sudah sesuai antara indikator dan soalnya tetapi perlu beberapa perbaikan diantaranya gambar-gambar perlu diperbaiki jika diperlukan digambar secara manual, gambar diperjelas, ada soal yang dibebani konsep, sebaiknya diperbaiki bentuk dan jenis pertanyaan, ada pernyataan pada soal yang perlu perbaikan, ada beberapa soal yang bukan soal inkuiri, sebaiknya soal-soal dibuat inkuiri induktif yang diperoleh dari penelitian siswa. 
4. Seorang pakar penelitian dan evaluasi pendidikan UNJ menyarankan ada soal yang kata kerjanya harus diubah menggunakan kata kerja operasional, soal yang menggunakan gambar harus diperjelas, ada soal yang gambarnya tidak berfungsi atau tidak banyak membantu, tetapi pada dasarnya indikator dan soal sudah sesuai.

5. Sebanyak 45 panelis menyarankan gambargambar sebaiknya diperjelas dan soal yang tidak membutuhkan gambar sebaiknya tidak perlu disajikan gambar, beberapa penyataan perlu perbaikan tetapi pada dasarnya indikator dan soal sudah sesuai.

Instrumen Kemampuan Inkuiri Ilmiah Siswa SMP, disertai dengan rubrik penilaian dan pedoman penskoran soal uraian obyektif. Adapun hasil validasi pakar (panelis) secara kuantitatif dengan menghitung nilai CVR (seperti tertera pada Tabel 3 berikut ini:

Tabel 3. Hasil Validasi Pakar (Panelis) Validasi Isi dengan CVR

\begin{tabular}{|c|c|c|c|c|c|c|}
\hline $\begin{array}{c}\text { No. } \\
\text { Soal }\end{array}$ & $\begin{array}{c}\text { Mp } \\
(Y a)\end{array}$ & $M$ & $M / 2$ & $\begin{array}{c}M p- \\
M / 2\end{array}$ & $\frac{M p-M / 2}{M / 2}$ & $\begin{array}{c}\text { Kete } \\
\text { rangan }\end{array}$ \\
\hline 1 & 46 & 49 & 24,5 & 21,5 & 0,8775 & $\begin{array}{c}\text { sangat } \\
\text { sesuai }\end{array}$ \\
\hline 2 & 38 & 49 & 24,5 & 13,5 & 0,5510 & sesuai \\
\hline 3 & 43 & 49 & 24,5 & 18,5 & 0,7551 & $\begin{array}{c}\text { sangat } \\
\text { sesuai }\end{array}$ \\
\hline 4 & 36 & 49 & 24,5 & 11,5 & 0,4693 & sesuai \\
\hline 5 & 33 & 49 & 24,5 & 8,5 & 0,3469 & sesuai \\
\hline 6 & 38 & 49 & 24,5 & 13,5 & 0,5510 & sesuai \\
\hline 7 & 42 & 49 & 24,5 & 17,5 & 0,7142 & $\begin{array}{c}\text { sangat } \\
\text { sesuai }\end{array}$ \\
\hline 8 & 41 & 49 & 24,5 & 16,5 & 0,6734 & sesuai \\
\hline 9 & 41 & 49 & 24,5 & 16,5 & 0,6734 & sesuai \\
\hline 10 & 33 & 49 & 24,5 & 8,5 & 0,3469 & sesuai \\
\hline 11 & 46 & 49 & 24,5 & 21,5 & 0,8775 & $\begin{array}{c}\text { sangat } \\
\text { sesuai }\end{array}$ \\
\hline 12 & 44 & 49 & 24,5 & 19,5 & 0,7959 & $\begin{array}{c}\text { sangat } \\
\text { sesuai }\end{array}$ \\
\hline 13 & 36 & 49 & 24,5 & 11,5 & 0,4693 & sesuai \\
\hline 14 & 33 & 49 & 24,5 & 8,5 & 0,3469 & sesuai \\
\hline 15 & 44 & 49 & 24,5 & 19,5 & 0,7959 & $\begin{array}{c}\text { sangat } \\
\text { sesuai }\end{array}$ \\
\hline 16 & 41 & 49 & 24,5 & 16,5 & 0,6734 & sesuai \\
\hline 17 & 33 & 49 & 24,5 & 8,5 & 0,3469 & sesuai \\
\hline 18 & 45 & 49 & 24,5 & 20,5 & 0,8367 & $\begin{array}{c}\text { sangat } \\
\text { sesuai }\end{array}$ \\
\hline 19 & 42 & 49 & 24,5 & 17,5 & 0,7142 & $\begin{array}{c}\text { sangat } \\
\text { sesuai }\end{array}$ \\
\hline
\end{tabular}

\begin{tabular}{|c|c|c|c|c|c|c|}
\hline $\begin{array}{l}\text { No. } \\
\text { Soal }\end{array}$ & $\begin{array}{l}\text { Mp } \\
(\mathrm{Ya})\end{array}$ & $M$ & $M / 2$ & $\begin{array}{l}\mathrm{Mp}- \\
\mathrm{M} / 2\end{array}$ & $\frac{M p-M / 2}{M / 2}$ & $\begin{array}{c}\text { Kete } \\
\text { rangan }\end{array}$ \\
\hline 20 & 42 & 49 & 24,5 & 17,5 & 0,7142 & $\begin{array}{l}\text { sangat } \\
\text { sesuai }\end{array}$ \\
\hline 21 & 33 & 49 & 24,5 & 8,5 & 0,3469 & sesuai \\
\hline 22 & 41 & 49 & 24,5 & 16,5 & 0,6734 & sesuai \\
\hline 23 & $4 I$ & 49 & 24,5 & 16,5 & 0,6734 & sesuai \\
\hline 24 & 40 & 49 & 24,5 & 15,5 & 0,6326 & sesuai \\
\hline 25 & 40 & 49 & 24,5 & 15,5 &, 6326 & sesuai \\
\hline 26 & 38 & 49 & 24,5 & 13,5 & 5510 & sesuai \\
\hline 27 & 37 & 49 & 24,5 & 12,5 & 0,5102 & sesuai \\
\hline 28 & 44 & 49 & 24,5 & 19,5 & 0,7959 & $\begin{array}{l}\text { sangat } \\
\text { sesuai }\end{array}$ \\
\hline 29 & 46 & 49 & 24,5 & 21,5 & 0,8775 & $\begin{array}{l}\text { sangat } \\
\text { sesuai }\end{array}$ \\
\hline 30 & 39 & 49 & 24,5 & 14,5 & 5918 & sesuai \\
\hline 31 & 36 & 49 & 24,5 & 11,5 & 4693 & sesuai \\
\hline 32 & 40 & 49 & 24,5 & 15,5 & 0,6326 & sesuai \\
\hline 33 & 42 & 49 & 24,5 & 17,5 & $0,7 \mid 42$ & sesuai \\
\hline 34 & $4 I$ & 49 & 24,5 & 16,5 & 0,6734 & sesuai \\
\hline 35 & 36 & 49 & 24,5 & 11,5 & 0,4693 & sesuai \\
\hline 36 & 43 & 49 & 24,5 & 18,5 & 551 & $\begin{array}{l}\text { sangat } \\
\text { sesuai }\end{array}$ \\
\hline 37 & 41 & 49 & 24,5 & 16,5 & 6734 & sesuai \\
\hline 38 & 37 & 49 & 24,5 & 12,5 & 0,5102 & sesuai \\
\hline 39 & 42 & 49 & 24,5 & 17,5 & & $\begin{array}{l}\text { sangat } \\
\text { sesuai }\end{array}$ \\
\hline 40 & 40 & 49 & 24,5 & 15,5 & 6326 & sesuai \\
\hline 41 & 42 & 49 & 24,5 & 17,5 & 7142 & $\begin{array}{l}\text { sangat } \\
\text { sesuai }\end{array}$ \\
\hline 42 & 35 & 49 & 24,5 & 10,5 & 0,4285 & sesuai \\
\hline 43 & 40 & 49 & 24,5 & 15,5 & & sesuai \\
\hline 44 & 38 & 49 & 24,5 & 13,5 & 10 & sesuai \\
\hline 45 & 35 & 49 & 24,5 & 10,5 & 285 & sesuai \\
\hline 46 & 39 & 49 & 24,5 & 14,5 & 5918 & sesuai \\
\hline 47 & 40 & 49 & 24,5 & 15,5 & 6326 & sesuai \\
\hline 48 & 39 & 49 & 24,5 & 14,5 & 0,5918 & sesuai \\
\hline 49 & 46 & 49 & 24,5 & 21,5 & 0,8775 & $\begin{array}{l}\text { sangat } \\
\text { sesuai }\end{array}$ \\
\hline 50 & 43 & 49 & 24,5 & 18,5 & 0,755 I & $\begin{array}{l}\text { sangat } \\
\text { sesuai }\end{array}$ \\
\hline 51 & 43 & 49 & 24,5 & 18,5 & ,755I & $\begin{array}{l}\text { sangat } \\
\text { sesuai }\end{array}$ \\
\hline 52 & 43 & 49 & 24,5 & 18,5 & 0,755 I & $\begin{array}{l}\text { sangat } \\
\text { sesuai }\end{array}$ \\
\hline 53 & 43 & 49 & 24,5 & 18,5 & 551 & $\begin{array}{l}\text { sangat } \\
\text { sesuai }\end{array}$ \\
\hline 54 & 34 & 49 & 24,5 & 9,5 & 0,3877 & sesuai \\
\hline 55 & 40 & 49 & 24,5 & 15,5 & 0,6326 & sesuai \\
\hline 56 & 33 & 49 & 24,5 & 8,5 & 0,3469 & sesuai \\
\hline 57 & 34 & 49 & 24,5 & 9,5 & 0,3877 & sesu \\
\hline
\end{tabular}

Berdasarkan hasil validasi pakar (panelis) sesuai tabel di atas dan berdasarkan saran pakar atau penilaian panelis maka dilakukanlah revisi instrumen. Setelah konsep instrumen dianggap 
valid secara teoretik dilanjutkan penggandaan instrumen sebanyak 300 bendel untuk keperluan uji coba. Uji coba pertama diberikan kepada siswa kelas IX SMPN 12 kota Tangerang Selatan tahun pelajaran 2014 - 2015 pada hari Selasa, 20 Januari 2015. Peserta uji coba sebanyak 316 siswa, siswa yang tidak dapat mengikuti sebanyak 15 siswa. Sehingga ada $30 \mathrm{l}$ siswa yang mengikuti uji coba. Uji coba kedua sebanyak 244 siswa kelas IX kota Tangerang Selatan tahun pelajaran 2015-2016 dilaksanakan pada hari Senin, I4 Desember 2015.

\section{Hasil Pengujian Hipotesis Pembahasan}

Hasil pengujian validitas empirik dalam pengembangan instrumen Kemampuan Inkuiri Ilmiah Siswa SMP, untuk mata pelajaran Biologi peneliti melakukan dalam dua tahap, yaitu:

I. Validasi Empirik Tahap pertama dan Reliabilitas

a. Hasil uji coba empiris tahap pertama dan penetapan butir yang valid menggunakan analisis factor

I) Dimensi Menganalisis (Analysis) dan memanfaatkan/menggunakan pengetahu an (Knowledge Utilization) pentingnya pertumbuhan dan perkembangan pada makhluk hidup

Dimensi pertama memiliki 9 item yang mengukur tentang pentingnya pertumbuhan dan perkembangan makhluk hidup. Adapun hasil analisis CFA terhadap dimensi tersebut dapat dilihat hasilnya pada Gambar I berikut ini:

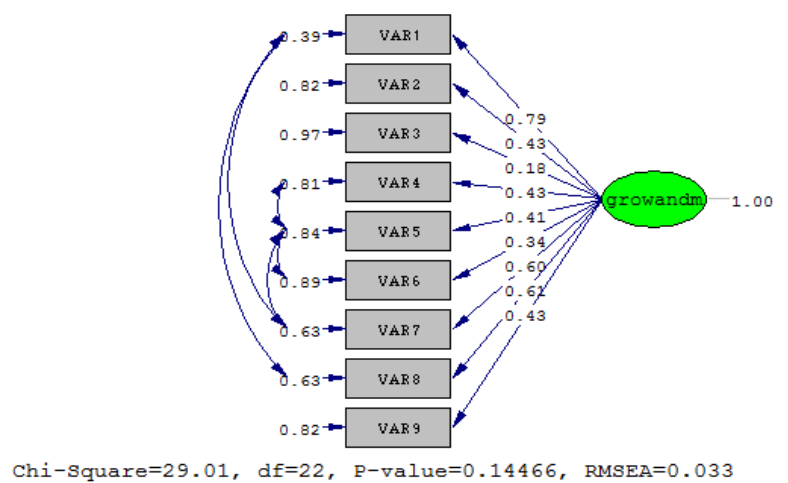

Gambar I. Model FIT Dimensi I
Sebagaimana Gambar I tersebut dapat dilihat bahwa dimensi I dinyatakan fit dengan nilai chi square sebesar 29,0l, $d f=22(p>0,05)$. Dengan demikian model unidimensional pada dimensi I dinyatakan fit, artinya tidak ada perbedaan antara model teoretis dengan model empiris. Namun demikian, pada model fit tersebut terdapat beberapa kesalahan pengukuran item yang saling berkorelasi satu sama lain. Padahal seharusnya korelasi kesalahan pengukuran tersebut idealnya tidak terjadi. Oleh karenanya, penulis melaporkan mengenai validitas tiap item $\mathrm{di}$ atas, sehingga informasi tentang validasi pada tingkat item tetap dapat diperoleh. Adapun informasinya terlihat pada Tabel 4 berikut ini:

Tabel 4. Koefisien Muatan Faktor Item Dimensi I

\begin{tabular}{|c|c|c|c|c|}
\hline $\begin{array}{c}\text { No } \\
\text { Item }\end{array}$ & Koefisien & $\begin{array}{c}\text { Std. } \\
\text { error }\end{array}$ & $\begin{array}{c}\text { Nilai } \\
\mathbf{t}\end{array}$ & Keterangan \\
\hline I & 0,79 & 0,07 & $\mathrm{II}, 3 \mathrm{I}$ & Valid \\
\hline 2 & 0,43 & 0,06 & 7,48 & Valid \\
\hline 3 & 0,18 & 0,06 & 3,14 & Valid \\
\hline 4 & 0,43 & 0,06 & 7,52 & Valid \\
\hline 5 & $0,4 \mathrm{I}$ & 0,06 & 6,82 & Valid \\
\hline 6 & 0,34 & 0,06 & 5,88 & Valid \\
\hline 7 & 0,60 & 0,07 & $8,9 \mathrm{I}$ & Valid \\
\hline 8 & $0,6 \mathrm{I}$ & 0,06 & $9,4 \mathrm{I}$ & Valid \\
\hline 9 & 0,43 & 0,06 & 7,47 & Valid \\
\hline
\end{tabular}

Berdasarkan Tabel 4 tersebut, dapat dilihat bahwa seluruh item dinyatakan valid. Sebab tidak ada satupun item memiliki koefisien yang negatif dan tidak ada nilai $t$ yang kurang dari I,96 ( $\mathrm{t}<$ I,96). Dengan demikian seluruh item pada dimensi dinyatakan valid dan dapat digunakan semuanya.

2) Dimensi menganalisis (Analysis) dan memanfaatkan/menggunakan pengetahuan (Knowledge Utilization) tahapan perkembangan manusia

Pada dimensi yang kedua ini penulis menguji validitas model unidimensional dan validitas tiap item yang berjumlah 8 . Adapun hasilnya dapat dilihat pada Gambar 2 berikut ini: 


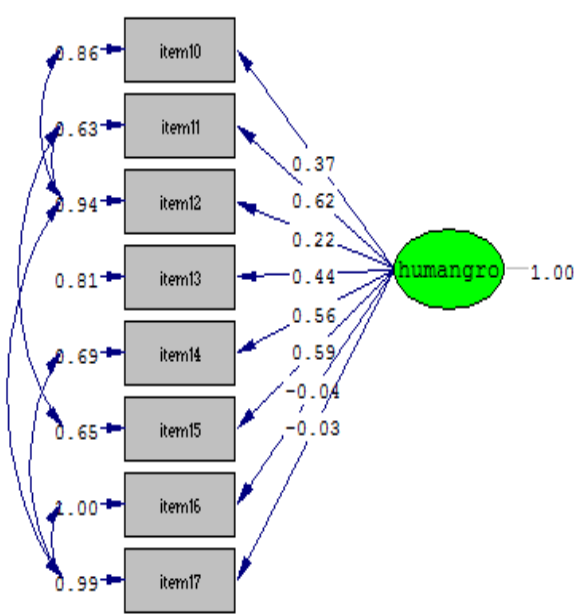

Chi-Square=20.09, df=14, P-value=0.12720, RMSEA $=0.038$

Gambar 2. Model FIT Dimensi 2

Berdasarkan Gambar 2 tersebut, dimensi kedua dinyatakan fit dengan nilai chi square sebesar 20,09, df $=14(p>0,05)$. Dengan demikian, tidak terdapat perbedaan antara model teoretis yang menyatakan bahwa model unidimensional dengan model empiris. Informasi selanjutnya yang dapat diketahui, yaitu: validitas pada tiap item. Adapun informasinya dapat dilihat pada Tabel 5. berikut ini:

Tabel 5. Koefisien Muatan Faktor Item Dimensi 2

\begin{tabular}{|c|c|c|c|c|}
\hline $\begin{array}{c}\text { No } \\
\text { Item }\end{array}$ & Koefisien & $\begin{array}{c}\text { Std. } \\
\text { error }\end{array}$ & $\begin{array}{c}\text { Nilai } \\
\mathbf{t}\end{array}$ & Keterangan \\
\hline I0 & 0,37 & 0,07 & 5,6 & Valid \\
\hline II & 0,62 & 0,08 & 7,72 & Valid \\
\hline I2 & 0,22 & 0,08 & 2,95 & Valid \\
\hline I3 & 0,44 & 0,07 & 6,68 & Valid \\
\hline I4 & 0,56 & 0,07 & 8,17 & Valid \\
\hline I5 & 0,59 & 0,08 & 7,42 & Valid \\
\hline I6 & $-0,04$ & 0,07 & $-0,59$ & Tidak Valid \\
\hline I7 & $-0,03$ & 0,07 & $-0,38$ & Tidak Valid \\
\hline
\end{tabular}

Berdasarkan Tabel 5 tersebut, dapat dilihat bahwa item yang dinyatakan tidak valid, yaitu: item 16 dan 17. Kedua item tersebut dinyatakan tidak valid dikarenakan koefisien item bersifat negatif dan nilai $t$ kurang dari 1,96. Dengan demikian, kedua item tersebut dinyatakan gugur atau tidak digunakan apabila terdapat kepentingan penelitian lebih lanjut, sedangkan sisa item lainnya dinyatakan valid.
3) Dimensi menganalisis (Analysis) dan memanfaatkan/menggunakan pengetahuan (Knowledge Utilization) sistem gerak pada manusia dan hubungannya dengan kesehatan

Pada tahap yang ketiga ini penulis menguji validitas dimensi gerak pada manusia dengan jumlah item sebanyak 10. Adapun hasilnya dapat dilihat pada Gambar 3 berikut ini:

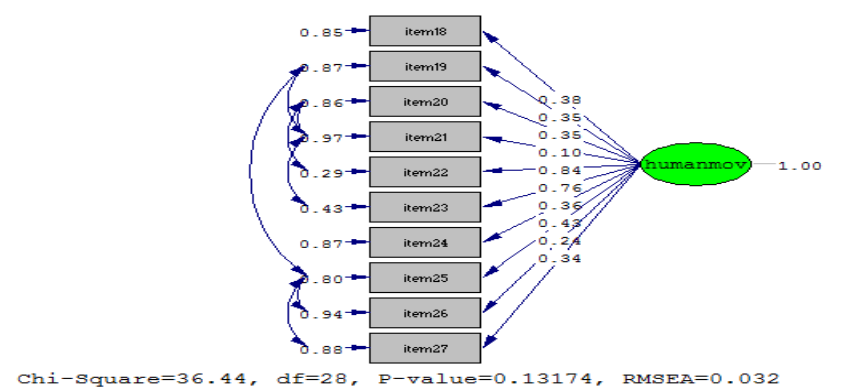

Gambar 3. Model FIT Dimensi 3

Berdasarkan Gambar 3 tersebut, model dimensi sistem gerak pada manusia dinyatakan fit dengan nilai chi square sebesar $36,44, \mathrm{df}=28(\mathrm{P}$ $>0,05)$. Dengan demikian tidak terdapat perbedaan antara model teoretis unidimensional dimensi 3 dengan model empiris. Informasi selanjutnya, yaitu: mengenai validitas tiap item. Adapun hasilnya dapat dilihat pada Tabel 6 berikut ini:

Tabel 6. Koefisien Muatan Faktor Item Dimensi 3

\begin{tabular}{|c|c|c|c|c|}
\hline $\begin{array}{c}\text { No } \\
\text { Item }\end{array}$ & Koefisien & $\begin{array}{c}\text { Std. } \\
\text { error }\end{array}$ & Nilai t & Keterangan \\
\hline 18 & 0,38 & 0,06 & 6,48 & Valid \\
\hline 19 & 0,35 & 0,06 & 5,83 & Valid \\
\hline 20 & 0,35 & 0,07 & 5,25 & Valid \\
\hline 21 & 0,1 & 0,06 & 1,55 & Tidak Valid \\
\hline 22 & 0,84 & 0,05 & 15,39 & Valid \\
\hline 23 & 0,76 & 0,06 & 13,74 & Valid \\
\hline 24 & 0,36 & 0,06 & 6,17 & Valid \\
\hline 25 & 0,43 & 0,06 & 7,33 & Valid \\
\hline 26 & 0,24 & 0,06 & 3,96 & Valid \\
\hline 27 & 0,34 & 0,06 & 5,8 & Valid \\
\hline
\end{tabular}

Berdasarkan Tabel 6 tersebut, item yang dinyatakan tidak valid, yaitu: item $2 \mathrm{I}$, dikarenakan 
item tersebut memiliki nilai $\mathrm{t}$ kurang dari I,96. Oleh karenanya item tersebut dinyatakan didrop. Sedangkan sisa item lainnya dinyatakan valid.

4) Dimensi menganalisis (Analysis) dan memanfaatkan/menggunakan pengetahuan (Knowledge Utilization) sistem pencernaan pada manusia dan hubungannya dengan kesehatan

Pada dimensi yang keempat ini penulis menguji unidimensionalitas dimensi sistem pencernaan pada manusia dan hubungannya dengan kesehatan. Dimensi ini terdiri dari 10 item. Adapun hasilnya dapat dilihat pada Gambar 4 berikut ini.

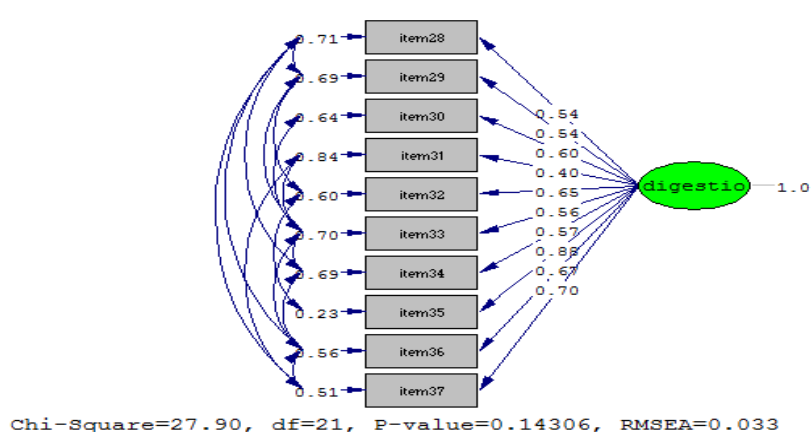

Gambar 4. Model FIT Dimensi 4

Berdasarkan Gambar 4 tersebut, dapat dilihat bahwa model unidimensional dimensi 4 tentang pengetahuan sistem pencernaan manusia dinyatakan fit, artinya tidak ada perbedaan antara model teoretis dengan model empiris. Adapun nilai chi square model di atas sebesar $27,90, \mathrm{df}=$ 2 I $(p>0,05)$. Informasi selanjutnya yang dapat diperoleh, yaitu: mengenai informasi validitas tiap item. Adapun hasilnya dapat dilihat pada Tabel 7 berikut ini:

Tabel 7. Koefisien Muatan Faktor Item Dimensi 4

\begin{tabular}{|c|c|c|c|c|}
\hline $\begin{array}{c}\text { No } \\
\text { Item }\end{array}$ & Koefisien & $\begin{array}{c}\text { Std. } \\
\text { error }\end{array}$ & Nilai t & Keterangan \\
\hline 28 & 0,54 & 0,05 & 10,52 & Valid \\
\hline 29 & 0,54 & 0,06 & 9.59 & Valid \\
\hline 30 & 0,6 & 0,05 & 11,63 & Valid \\
\hline 31 & 0,4 & 0,05 & $7,6 \mathrm{I}$ & Valid \\
\hline 32 & 0,65 & 0,06 & $\mathrm{II}, 08$ & Valid \\
\hline 33 & 0,56 & 0,05 & 10,79 & Valid \\
\hline
\end{tabular}

\begin{tabular}{|c|c|c|c|c|}
\hline $\begin{array}{c}\text { No } \\
\text { Item }\end{array}$ & Koefisien & $\begin{array}{c}\text { Std. } \\
\text { error }\end{array}$ & Nilai t & Keterangan \\
\hline 34 & 0,57 & 0,05 & $\mathrm{II}, \mathrm{I}$ & Valid \\
\hline 35 & 0,88 & 0,05 & 17,82 & Valid \\
\hline 36 & 0,67 & 0,05 & 13,29 & Valid \\
\hline 37 & 0,7 & 0,05 & 14,15 & Valid \\
\hline
\end{tabular}

Berdasarkan Tabel 7 tersebut terlihat bahwa seluruh item dinyatakan valid. Dengan demikian, jika ada kepentingan penelitian lebih lanjut, maka tidak ada satupun item dimensi pengetahuan tentang sistem pencernaan yang di drop.

5) Dimensi menganalisis (Analysis) dan memanfaatkan/menggunakan pengetahuan (Knowledge Utilization) sistem pernapasan pada manusia dan hubungannya dengan kesehatan

Pada tahap kelima ini penulis menguji unidimensionalitas aspek atau dimensi sistem pernapasan pada manusia dan hubungannya dengan kesehatan. Aspek ini terdiri dari 10 item. Berikut hasil analisis CFA yang penulis lakukan:

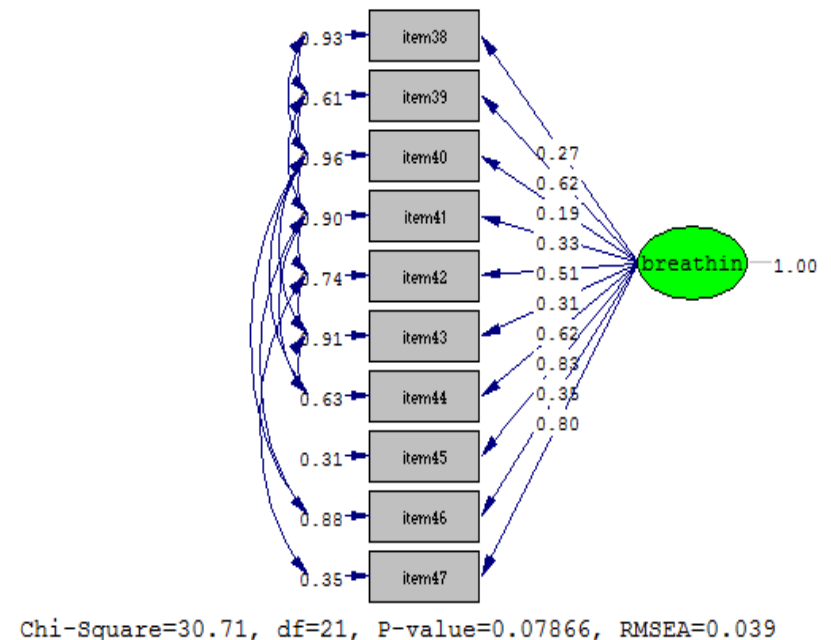

Gambar 5. Model FIT Dimensi 5

Berdasarkan Gambar 5 tersebut, terlihat bahwa model tentang pengetahuan sistem pernapasan pada manusia dinyatakan fit dengan nilai chi square sebesar $30,7 \mathrm{l}$ dan $\mathrm{df}=2 \mathrm{l}(\mathrm{p}>$ $0,05)$. Dengan demikian tidak ada perbedaan antara model teoretis dengan model empiris. Informasi selanjutnya, yaitu: mengenai validitas tiap item. Adapun hasilnya pada Tabel 8 berikut: 
Tabel 8. Koefisien Muatan Faktor Item Dimensi 5

\begin{tabular}{|c|c|c|c|c|}
\hline $\begin{array}{c}\text { No } \\
\text { Item }\end{array}$ & Koefisien & $\begin{array}{c}\text { Std. } \\
\text { error }\end{array}$ & $\begin{array}{c}\text { Nilai } \\
\mathbf{t}\end{array}$ & Keterangan \\
\hline 38 & 0,27 & 0,06 & 4,35 & Valid \\
\hline 39 & 0,62 & 0,06 & $\mathrm{II}, 12$ & Valid \\
\hline 40 & 0,19 & 0,06 & 3,05 & Valid \\
\hline $4 \mathrm{I}$ & 0,33 & 0,06 & 5,27 & Valid \\
\hline 42 & $0,5 \mathrm{I}$ & 0,06 & 8,44 & Valid \\
\hline 43 & $0,3 \mathrm{I}$ & 0,06 & 5,06 & Valid \\
\hline 44 & 0,62 & 0,06 & $\mathrm{II}, 02$ & Valid \\
\hline 45 & 0,83 & 0,05 & $16,4 \mathrm{I}$ & Valid \\
\hline 46 & 0,35 & 0,06 & 5,85 & Valid \\
\hline 47 & 0,8 & 0,05 & $\mathrm{I} 5,47$ & Valid \\
\hline
\end{tabular}

Berdasarkan Tabel 8 tersebut, seluruh item dinyatakan valid sebab tidak ada item yang berkoefisien negatif dan tidak ada nilai $t$ yang kurang dari I,96 ( $t>1,96)$. Dengan demikian, pada dimensi 5 ini tidak ada satupun item yang perlu di drop.

6) Dimensi menganalisis (Analysis) dan memanfaatkan/menggunakan pengetahuan (Knowledge Utilization) sistem peredaran darah pada manusia dan hubungannya dengan kesehatan

Pada tahap keenam ini penulis menguji validitas item pada dimensi sistem peredaran darah pada manusia dan hubungannya dengan kesehatan. Item pada dimensi ini terdiri dari 10 item. Adapun hasilnya dapat dilihat pada Gambar 6 berikut ini:

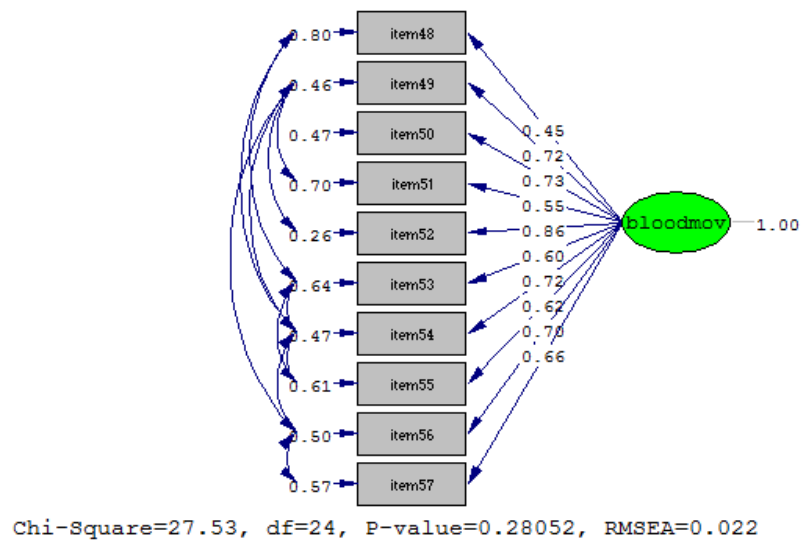

Gambar 6. Model FIT Dimensi 6
Berdasarkan Gambar 6 tersebut, terlihat bahwa model unidimensional dimensi tentang sistem peredaran darah pada manusia dinyatakan fit, dengan nilai chi square sebesar 27, 53 dan df $=24(p>0,05)$. Artinya tidak ada perbedaan antara model data teoretis dengan model data empiris yang diperoleh dari lapangan. Seperti sebelumnya, informasi terakhir yang dapat diperoleh, yaitu: informasi tentang validitas pada tingkatan item. hasilnya dapat dilihat pada Tabel 9 berikut ini:

Tabel 9. Koefisien Muatan Faktor Item Dimensi 6

\begin{tabular}{|c|c|c|c|c|}
\hline $\begin{array}{c}\text { No } \\
\text { Item }\end{array}$ & Koefisien & $\begin{array}{c}\text { Std. } \\
\text { error }\end{array}$ & $\begin{array}{c}\text { Nilai } \\
\mathbf{t}\end{array}$ & Keterangan \\
\hline 48 & 0,45 & 0,06 & 7,95 & Valid \\
\hline 49 & 0,72 & 0,05 & 13,27 & Valid \\
\hline 50 & 0,73 & 0,05 & 14,3 & Valid \\
\hline 51 & 0,55 & 0,06 & 9,7 & Valid \\
\hline 52 & 0,86 & 0,05 & 17,78 & Valid \\
\hline 53 & 0,6 & 0,05 & 10,99 & Valid \\
\hline 54 & 0,72 & 0,05 & 13,82 & Valid \\
\hline 55 & 0,62 & 0,05 & 11,58 & Valid \\
\hline 56 & 0,7 & 0,05 & 13,19 & Valid \\
\hline 57 & 0,66 & 0,05 & 12,48 & Valid \\
\hline
\end{tabular}

Berdasarkan Tabel 9 tersebut, dapat dinyatakan bahwa seluruh item dinyatakan valid. Sebab tidak ada satupun item pada dimensi pengetahuan tentang sistem peredaran darah pada manusia yang memiliki koefisien negatif serta nilai $t$ semua item tersebut lebih besar dari I,96 $(t>1,96)$. Dengan demikian, tidak ada item yang didrop.

b. Hasil penghitungan koefisien reliabilitas

Tabel 10. Konstruk reliabilitas tahap pertama

\begin{tabular}{|c|c|c|c|c|}
\hline Loading & Loading $^{2}$ & Error & $\begin{array}{r}\text { Loading }^{2} \\
\text { Error }\end{array}$ & CR \\
\hline 28,65 & 820,8225 & 3,38 & 824,2025 & 0,9958 \\
\hline
\end{tabular}


Tabel II. Variance extracted tahap pertama

\begin{tabular}{|c|c|c|c|}
\hline$\sum$ Loading & Error & $\begin{array}{c}\sum \text { Loading }^{2+} \\
\text { Error }\end{array}$ & VE \\
\hline 16,9809 & 3,38 & 20,3609 & 0,8339 \\
\hline
\end{tabular}

Hasil perhitungan menunjukkan bahwa construct reliability sebesar 0,9958 $(>0,70)$, dan Variance Extract 0,8339 $(>0,5)$, dengan demikian dapat disimpulkan bahwa reliabilitas pada konstruk telah terpenuhi. Makin besar nilai ini, menunjukkan bahwa indikator-indikator penyusun bagi suatu peubah laten merupakan indikator-indikator yang handal dalam mengukur peubah laten tersebut. Nilai kehandalan konstruk yang disarankan adalah lebih besar dari 0,7. Sedangkan ukuran kelayakan variance extracted yang disarankan adalah lebih besar dari 0,5.

2. Validasi Empirik Tahap Kedua dan Reliabilitas

a. Hasil uji coba empiris tahap kedua dan penetapan butir yang valid menggunakan analisis faktor

7) Dimensi menganalisis (Analysis) dan memanfaatkan/menggunakan pengetahuan (Knowledge Utilization) tahapan perkembangan manusia

Pada dimensi yang kedua ini penulis menguji validitas model unidimensional dan validitas tiap item yang berjumlah 8 . Adapun hasilnya dapat dilihat pada Gambar 7 berikut ini:

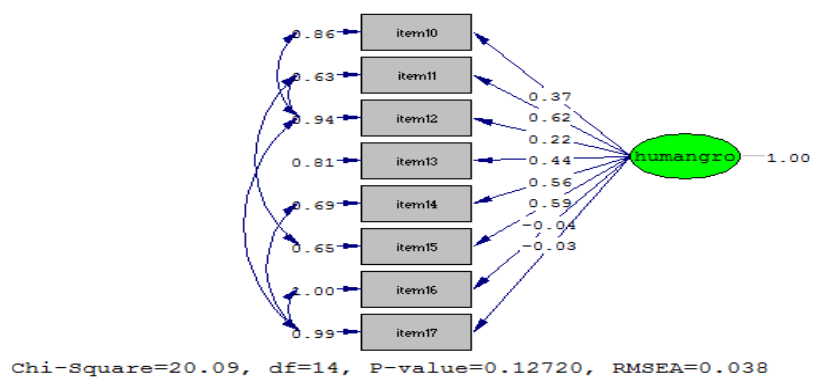

Gambar 7. Model FIT Dimensi 2.I

Berdasarkan Gambar 7 tersebut, dimensi 2.I dinyatakan fit dengan nilai chi square sebesar
20,09, $d f=14(p>0,05)$. Dengan demikian, tidak terdapat perbedaan antara model teoretis yang menyatakan bahwa model unidimensional dengan model empiris. Informasi selanjutnya yang dapat diketahui, yaitu: validitas pada tiap item. Adapun informasinya dapat dilihat pada Tabel 12 berikut ini:

Tabel 12. Koefisien Muatan Faktor Item Dimensi 2.I

\begin{tabular}{|c|c|c|c|c|}
\hline $\begin{array}{c}\text { No } \\
\text { Item }\end{array}$ & Koefisien & $\begin{array}{c}\text { Std. } \\
\text { error }\end{array}$ & $\begin{array}{c}\text { Nilai } \\
\mathbf{t}\end{array}$ & Keterangan \\
\hline 10 & 0,37 & 0,07 & 5,6 & Valid \\
\hline II & 0,62 & 0,08 & 7,72 & Valid \\
\hline 12 & 0,22 & 0,08 & 2,95 & Valid \\
\hline 13 & 0,44 & 0,07 & 6,68 & Valid \\
\hline 14 & 0,56 & 0,07 & 8,17 & Valid \\
\hline 15 & 0,59 & 0,08 & 7,42 & Valid \\
\hline 16 & $-0,04$ & 0,07 & $-0,59$ & Tidak Valid \\
\hline 17 & $-0,03$ & 0,07 & $-0,38$ & Tidak Valid \\
\hline
\end{tabular}

Berdasarkan Tabel 12 tersebut, dapat dilihat bahwa item yang dinyatakan tidak valid, yaitu: item 16 dan 17. Kedua item tersebut dinyatakan tidak valid karena koefisien item bersifat negatif dan nilai $t$ kurang dari I,96. Dengan demikian, kedua item tersebut dinyatakan gugur atau tidak digunakan apabila terdapat kepentingan penelitian lebih lanjut, sedangkan sisa item lainnya dinyatakan valid.

Berdasarkan Tabel 12 tersebut, penulis menguji ulang validitas model unidimensional dan validitas tiap item yang berjumlah 6 . Adapun hasilnya dapat dilihat pada Gambar 8 berikut ini:

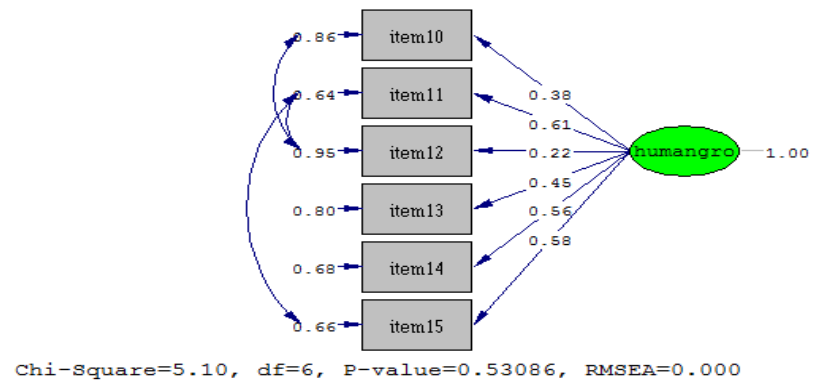

Gambar 8. Model FIT Dimensi 2.2

Berdasarkan Gambar 8 tersebut, dimensi ke 2.2 dinyatakan fit dengan nilai chi square 
sebesar 5,10, df = $6(p>0,05)$. Dengan demikian, tidak terdapat perbedaan antara model teoretis yang menyatakan bahwa model unidimensional dengan model empiris. Informasi selanjutnya yang dapat diketahui, yaitu: validitas pada tiap item. Adapun informasinya dapat dilihat pada Tabel I3 berikut ini:

Tabel I3. Koefisien Muatan Faktor Item Dimensi 2.2

\begin{tabular}{|c|c|c|c|c|}
\hline $\begin{array}{c}\text { No } \\
\text { Item }\end{array}$ & Koefisien & $\begin{array}{c}\text { Std. } \\
\text { error }\end{array}$ & Nilai t & Keterangan \\
\hline 10 & 0,38 & 0,07 & 5,69 & Valid \\
\hline II & 0,61 & 0,08 & 7,72 & Valid \\
\hline 12 & 0,22 & 0,08 & 2,93 & Valid \\
\hline 13 & 0,45 & 0,07 & 6,69 & Valid \\
\hline 14 & 0,56 & 0,07 & 8,23 & Valid \\
\hline 15 & 0,58 & 0,08 & 7,25 & Valid \\
\hline
\end{tabular}

Berdasarkan Tabel 13 tersebut, dapat dilihat seluruh item pada dimensi 2.2 dinyatakan valid. Dengan demikian, seluruh item dapat digunakan untuk menghitung faktor skor atau kepentingan penelitian selanjutnya.

8) Dimensi menganalisis (Analysis) dan memanfaatkan/menggunakan pengetahuan (Knowledge Utilization) sistem gerak pada manusia dan hubungannya dengan kesehatan

Pada dimensi yang ke 3 ini penulis menguji validitas dimensi gerak pada manusia dan hubungannya dengan kesehatan dengan jumlah item sebanyak 10 .

Adapun hasilnya dapat dilihat pada Gambar 9 berikut ini:

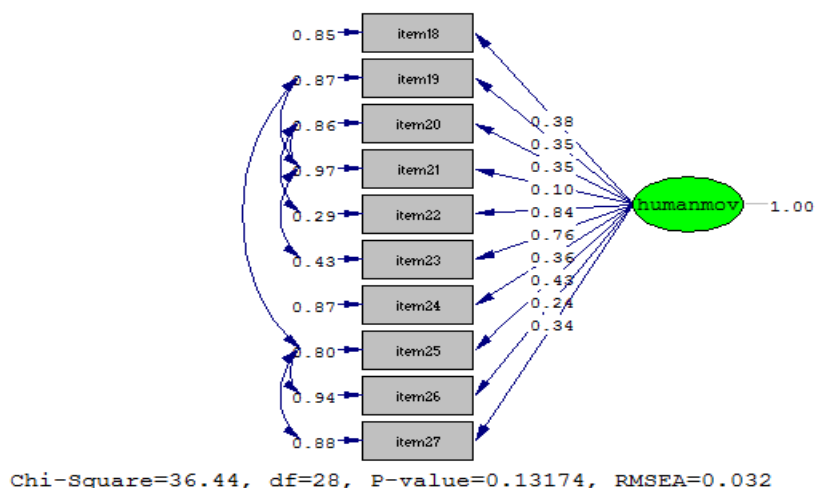

Gambar 9. Model FIT Dimensi 3.I
Berdasarkan Gambar 9 tersebut, model dimensi sistem gerak pada manusia dinyatakan fit dengan nilai chi square sebesar 36,44, df $=28(p$ $>$ 0,05). Dengan demikian tidak terdapat perbedaan antara model teoretis unidimensional dimensi 3 dengan model empiris. Informasi selanjutnya, yaitu: mengenai validitas tiap item. Adapun hasilnya dapat dilihat pada Tabel 14 berikut ini:

Tabel 14. Koefisien Muatan Faktor Item Dimensi 3.I

\begin{tabular}{|c|c|c|c|c|}
\hline $\begin{array}{c}\text { No } \\
\text { Item }\end{array}$ & Koefisien & $\begin{array}{c}\text { Std. } \\
\text { error }\end{array}$ & Nilai t & Keterangan \\
\hline 18 & 0,38 & 0,06 & 6,48 & Valid \\
\hline 19 & 0,35 & 0,06 & 5,83 & Valid \\
\hline 20 & 0,35 & 0,07 & 5,25 & Valid \\
\hline 21 & $0, I$ & 0,06 & 1,55 & Tidak Valid \\
\hline 22 & 0,84 & 0,05 & 15,39 & Valid \\
\hline 23 & 0,76 & 0,06 & 13,74 & Valid \\
\hline 24 & 0,36 & 0,06 & 6,17 & Valid \\
\hline 25 & 0,43 & 0,06 & 7,33 & Valid \\
\hline 26 & 0,24 & 0,06 & 3,96 & Valid \\
\hline 27 & 0,34 & 0,06 & 5,8 & Valid \\
\hline
\end{tabular}

Berdasarkan Tabel I4 tersebut, item yang dinyatakan tidak valid, yaitu: item 21 , karena item tersebut memiliki nilai t kurang dari I,96. Oleh karenanya item tersebut dinyatakan didrop. Sedangkan sisa item lainnya dinyatakan valid. Berdasarkan Tabel I4 tersebut, penulis menguji ulang validitas model unidimensional dan validitas tiap item yang berjumlah 9. Adapun hasilnya dapat dilihat pada Gambar 10 berikut ini:

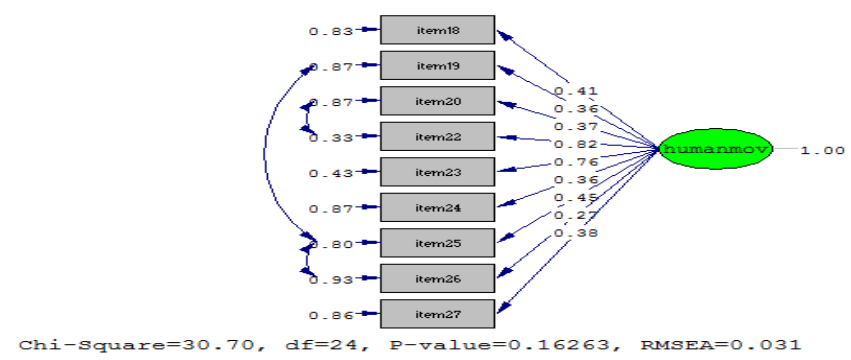

Gambar 10. Model FIT Dimensi 3.2

Berdasarkan Gambar 10 tersebut, model dimensi sistem gerak pada manusia dinyatakan fit dengan nilai chi square sebesar 30,70, $d f=24(P$ 
$>$ 0,05). Dengan demikian tidak terdapat perbedaan antara model teoretis unidimensional dimensi 3 dengan model empiris. Informasi selanjutnya, yaitu: mengenai validitas tiap item. Adapun hasilnya dapat dilihat pada Tabel 15 berikut ini:

Tabel 15. Koefisien Muatan Faktor Item Dimensi 3.2

\begin{tabular}{|c|c|c|c|c|}
\hline $\begin{array}{c}\text { No } \\
\text { Item }\end{array}$ & Koefisien & $\begin{array}{c}\text { Std. } \\
\text { error }\end{array}$ & $\begin{array}{c}\text { Nilai } \\
\mathbf{t}\end{array}$ & Keterangan \\
\hline 18 & 0,41 & 0,06 & 6,86 & Valid \\
\hline 19 & 0,36 & 0,06 & 5,87 & Valid \\
\hline 20 & 0,37 & 0,07 & 5,53 & Valid \\
\hline 22 & 0,82 & 0,06 & 14.92 & Valid \\
\hline 23 & 0,76 & 0,06 & 13,93 & Valid \\
\hline 24 & 0,36 & 0,06 & 5.94 & Valid \\
\hline 25 & 0,45 & 0,06 & 7,53 & Valid \\
\hline 26 & 0,27 & 0,06 & 4,35 & Valid \\
\hline 27 & 0,38 & 0,06 & 6,31 & Valid \\
\hline
\end{tabular}

Berdasarkan Tabel I5 tersebut, seluruh item pada dimensi 3 dinyatakan valid dan dapat digunakan semua untuk kepentingan penelitian lebih lanjut.

b. Hasil penghitungan koefisien reliabilitas

Tabel 16. Konstruk reliabilitas tahap kedua

\begin{tabular}{|c|c|c|c|c|}
\hline Loading & Loading $^{2}$ & Error & $\begin{array}{c}\text { Loading }^{2+} \\
\text { Error }\end{array}$ & CR \\
\hline 28,75 & 826,5625 & 3,18 & 829,7425 & 0,9961 \\
\hline
\end{tabular}

Tabel 17. variance extracted tahap kedua

\begin{tabular}{|c|c|c|c|}
\hline LLoading & Error & $\begin{array}{c}\text { Eloading } \\
\text { Error }\end{array}$ & VE \\
\hline 17,0345 & 3,18 & 20,2145 & 0,8426 \\
\hline
\end{tabular}

Hasil perhitungan menunjukkan bahwa construct reliability sebesar 0,9961 (> 0,70), dan Variance Extract $0,8426(>0,5)$, dengan demikian dapat disimpulkan bahwa reliabilitas pada konstruk telah terpenuhi. Makin besar nilai ini, menunjukkan bahwa indikator-indikator penyusun bagi suatu peubah laten merupakan indikator-indikator yang handal dalam mengukur peubah laten tersebut. Nilai kehandalan konstruk yang disarankan adalah lebih besar dari 0,7. Sedangkan ukuran kelayakan variance extracted yang disarankan adalah lebih besar dari 0,5 .

Dari 57 item setelah dianalisis dengan CFA, ada 54 item yang valid artinya tidak terdapat perbedaan antara model teoretis unidimensional dengan model empiris. Pada dimensi I yang terdiri dari 9 soal, seluruhnya valid. Pada dimensi 2 yang terdiri dari 8 soal, 6 soal valid dan 2 soal lainnya didrop. Pada dimensi 3 yang terdiri dari 10 soal, 9 soal valid dan I soal lainnya didrop. Pada dimensi 4 yang terdiri dari 10 soal, seluruhnya valid. Pada dimensi 5 yang terdiri dari 10 soal, seluruhnya valid. Pada dimensi 6 yang terdiri dari I0 soal, seluruhnya valid.

Dari 54 item setelah dianalisis dengan CFA pada uji coba kedua, ada 28 item yang valid artinya tidak terdapat perbedaan antara model teoretis unidimensional dengan model empiris. Pada dimensi I yang terdiri dari 9 soal, 4 soal valid, dan 5 soal didrop. Pada dimensi 2 yang terdiri dari 6 soal seluruhnya didrop. Pada dimensi 3 yang terdiri dari 9 soal, 2 soal valid dan 7 soal lainnya didrop. Pada dimensi 4 yang terdiri dari 10 soal, 8 soal valid, dan 2 soal didrop. Pada dimensi 5 yang terdiri dari 10 soal, 9 soal valid, dan I soal didrop. Pada dimensi 6 yang terdiri dari 10 soal, 5 soal valid, dan 5 soal didrop. Hasil penghitungan koefisien reliabilitas pada uji coba kedua $r=0,9825$ dengan koefisien reliabilitas > 0,70 , maka tes memiliki tingkat reliabilitas yang tinggi.

\section{Hasil Penelitian Uji Coba kedua}

a. Hasil uji coba empiris tahap uji coba kedua dan penetapan butir yang valid menggunakan analisis faktor

9) Dimensi Menganalisis (Analysis) dan memanfaatkan/menggunakan pengetahuan (Knowledge Utilization) pentingnya pertumbuhan dan perkembangan pada makhluk hidup

\section{Dimensi I}

Dimensi pertama memiliki 9 item yang mengukur tentang pentingnya pertumbuhan dan perkembangan makhluk hidup. Pada pemaparan 
berikut ini, penulis akan menjelaskan hasil analisis CFA dimensi pertama. Berdasarkan hasil analisis CFA awal, penulis mendrop item I, 5, 7, dan 9. $\mathrm{Hal}$ ini karena varians pada item tersebut sangat kecil sehingga tidak saling berkorelasi dengan item item lainnya pada dimensi yang sama. Bahkan item I, bersifat konstan. Dengan demikian, pada dimensi I ini penulis hanya menganalisis sisa item lainnya. Hasil awal CFA diperoleh hasil chi square sebesar 48,20, $d f=5(p<0,05)$. Karena hasil tersebut belum fit, maka penulis melakukan modifikasi pada model tersebut, sehingga diperoleh hasil seperti pada Gambar II berikut:

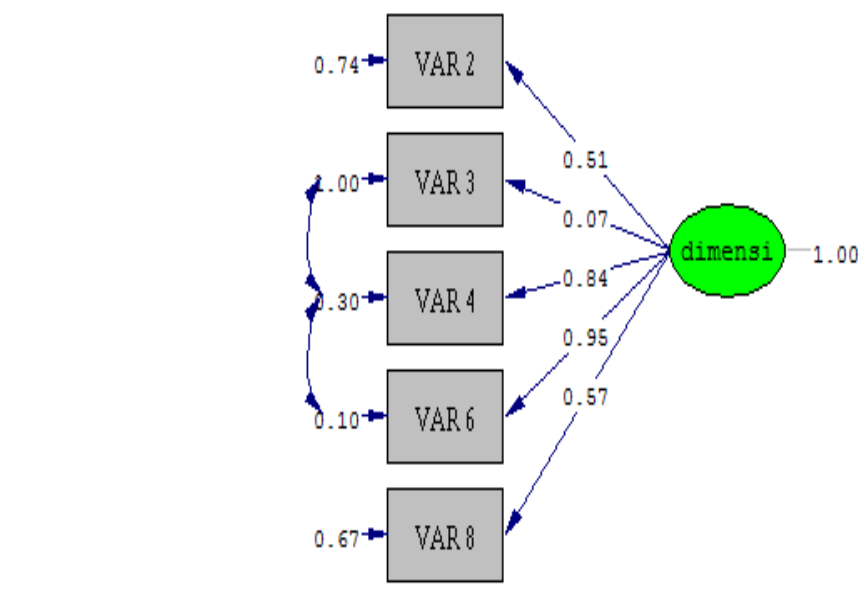

Chi-Square=1.66, df $=3, \mathrm{P}-\mathrm{value}=0.64554, \mathrm{RMSEA}=0.000$

Gambar II. Model FIT Dimensi I Uji coba 2

Berdasarkan Gambar II tersebut, model dimensi I dinyatakan fit dengan nilai chi square sebesar I,66, df $=3(p>0,05)$. Adapun pemaparan tiap hasil uji validitas item, akan penulis paparkan dalam Tabel 18 berikut ini:

Tabel I8. Koefisien Muatan Faktor Item Dimensi I

\begin{tabular}{|l|c|c|c|c|}
\hline Item & $\begin{array}{l}\text { Koefi } \\
\text { sien }\end{array}$ & $\begin{array}{l}\text { Std. } \\
\text { Error }\end{array}$ & $\begin{array}{c}\text { Nilai } \\
\mathbf{t}\end{array}$ & Keterangan \\
\hline Item 2 & $0,5 \mathrm{I}$ & 0,07 & 7,25 & Valid \\
\hline Item 3 & 0,07 & 0,07 & $\mathrm{I}$ & Tidak Valid \\
\hline Item 4 & 0,84 & 0,09 & 9,65 & Valid \\
\hline Item 6 & 0,95 & 0,09 & $10,6 \mathrm{I}$ & Valid \\
\hline Item 8 & 0,57 & 0,07 & $7,9 \mathrm{I}$ & Valid \\
\hline
\end{tabular}

Berdasarkan Tabel 18 tersebut, seluruh item dinyatakan valid. Kecuali item 3 Dengan demikian seluruh item yang valid di atas dapat digunakan apabila ada analisis statistik lebih lanjut.

\section{Dimensi 2}

Dimensi dua terdiri dari enam soal. Adapun hasil awal analisis CFA diperoleh bahwa seluruh item tidak valid.

\section{Dimensi 3}

Dimensi tiga terdiri dari sembilan soal. hasil awal analisis CFA pada dimensi tiga, diketahui bahwa model unidimensional dinyatakan tidak fit dengan nilai chi square sebesar 189,63, $d f=27 \quad(p<0,05)$. Karena masih tidak fit, maka penulis melakukan modifikasi pada model dengan hasil seperti pada Gambar 12 berikut ini:

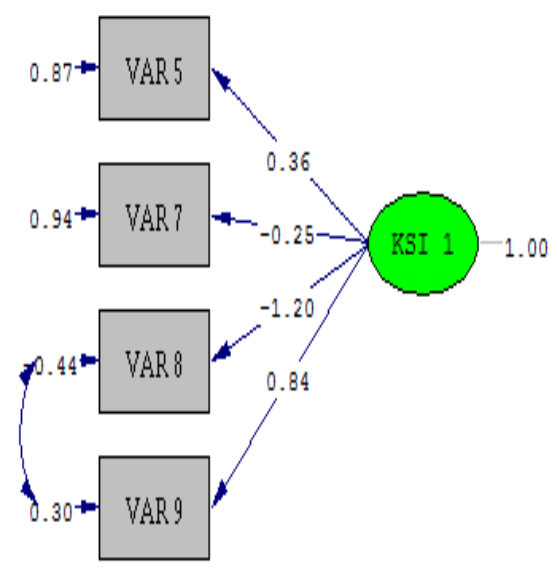

Chi-Square $=0.13, \mathrm{df}=1, \mathrm{p}$-value $=0.71690$, RMSEA $=0.000$

Gambar 12. Model FIT Dimensi 3 Uji coba 2

Berdasarkan Gambar 12 tersebut, terlihat bahwa model unidimensional dimensi tiga dinyatakan fit dengan nilai chi square sebesar $0,13, d f=I \quad(p>$ $0,05)$. Dengan demikian, dimensi tiga dinyatakan fit dengan hanya beberapa item yang dapat dianalisis. Adapun item soal yang dapat dianalisis hanyalah item 5 (nomor soal 23), 7 (nomor soal 25), 8 (nomor soal 26), dan 9 (nomor soal 27). Sedangkan sisanya, dinyatakan tidak dapat dianalisis. Selanjutnya penulis memaparkan tentang uji validitas tiap item, hasilnya seperti terlihat pada Tabel 19 berikut ini: 
Tabel 19. Koefisien Muatan Faktor Item Dimensi 3

\begin{tabular}{|l|l|l|l|l|}
\hline Item & $\begin{array}{l}\text { Koefi } \\
\text { sien }\end{array}$ & $\begin{array}{l}\text { Std. } \\
\text { Error }\end{array}$ & Nilai t & Keterangan \\
\hline Item 23 & 0,36 & 0,13 & $2,8 I$ & Valid \\
\hline Item 25 & $-0,25$ & 0,10 & $-2,48$ & Tidak Valid \\
\hline Item 26 & $-1,20$ & 0,38 & $-3,15$ & Tidak Valid \\
\hline Item 27 & 0,84 & 0,29 & $2,9 I$ & Valid \\
\hline
\end{tabular}

Berdasarkan Tabel 19 tersebut, diketahui bahwa hanya ada 2 item yang dinyatakan valid, yaitu: item 23 dan item 27, sedangkan sisa item lainnya dinyatakan tidak valid.

\section{Dimensi 4}

Dimensi empat memiliki 10 item. Hasil awal analisis CFA dimensi empat diperoleh bahwa nilai chi square sebesar 307,10, $d f=35(p<0,05)$. Dengan demikian model dimensi empat dinyatakan tidak fit. Oleh karena itu, penulis melakukan modifikasi model tersebut, sehingga diperoleh hasil seperti pada Gambar 13 berikut ini:

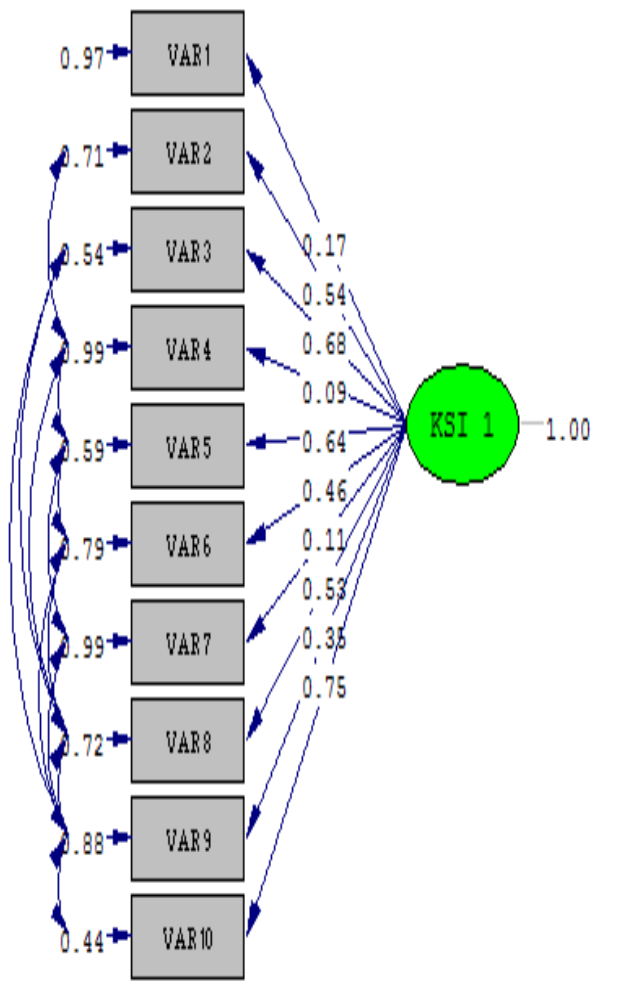

Chi-Square $=30.65, \mathrm{df}=23, \mathrm{p}$-value=0.13157, RMSEA $=0.037$

Gambar 13. Model FIT Dimensi 4 Uji coba 2
Berdasarkan Gambar 13 tersebut dapat dilihat bahwa model dimensi 4 dinyatakan fit dengan nilai chi square sebesar $30,65, d f=23(p>$ 0,05). Dengan demikian model dimensi 4 dinyatakan unidimensional. Selanjutnya penulis menuliskan informasi tentang uji validitas tiap item, hasilnya dapat dilihat pada Tabel 20 berikut ini:

Tabel 20. Koefisien Muatan Faktor Item Dimensi 4

\begin{tabular}{|l|l|l|l|l|}
\hline Item & $\begin{array}{l}\text { Koe } \\
\text { fisien }\end{array}$ & $\begin{array}{l}\text { Std. } \\
\text { Error }\end{array}$ & $\begin{array}{l}\text { Nilai } \\
\mathbf{t}\end{array}$ & Keterangan \\
\hline Item 28 & 0,17 & 0,07 & $2,5 \mathrm{I}$ & Valid \\
\hline Item 29 & 0,54 & 0,07 & 8,25 & Valid \\
\hline Item 30 & 0,68 & 0,06 & I0,5I & Valid \\
\hline Item 3I & 0,09 & 0,07 & $\mathrm{I}, \mathrm{I7}$ & Tidak Valid \\
\hline Item 32 & 0,65 & 0,06 & $\mathrm{I} 0,06$ & Valid \\
\hline Item 33 & 0,46 & 0,07 & 6,52 & Valid \\
\hline Item 34 & $0,1 \mathrm{I}$ & 0,07 & $\mathrm{I}, 53$ & Tidak Valid \\
\hline Item 35 & 0,52 & 0,07 & 7,53 & Valid \\
\hline Item 36 & 0,34 & 0,08 & 4,48 & Valid \\
\hline Item 37 & 0,75 & 0,06 & 12,48 & Valid \\
\hline
\end{tabular}

Berdasarkan Tabel 20 tersebut, terlihat bahwa hanya item 31 dan 34 yang dinyatakan tidak valid, sedangkan sisanya dinyatakan valid. Dengan demikian, item 31 dan 34 tidak digunakan apabila terdapat analisis lebih lanjut.

\section{Dimensi 5}

Dimensi 5 memiliki sepuluh item. Adapun hasil analisis CFA yang penulis peroleh, yaitu: chi square sebesar $218,99, d f=35(p<0,05)$. Dengan demikian, dimensi 5 dinyatakan tidak FIT. Oleh karena itu, penulis akan memodifikasi model tersebut, sehingga diperoleh hasil seperti terlihat pada Gambar 14 berikut ini: 


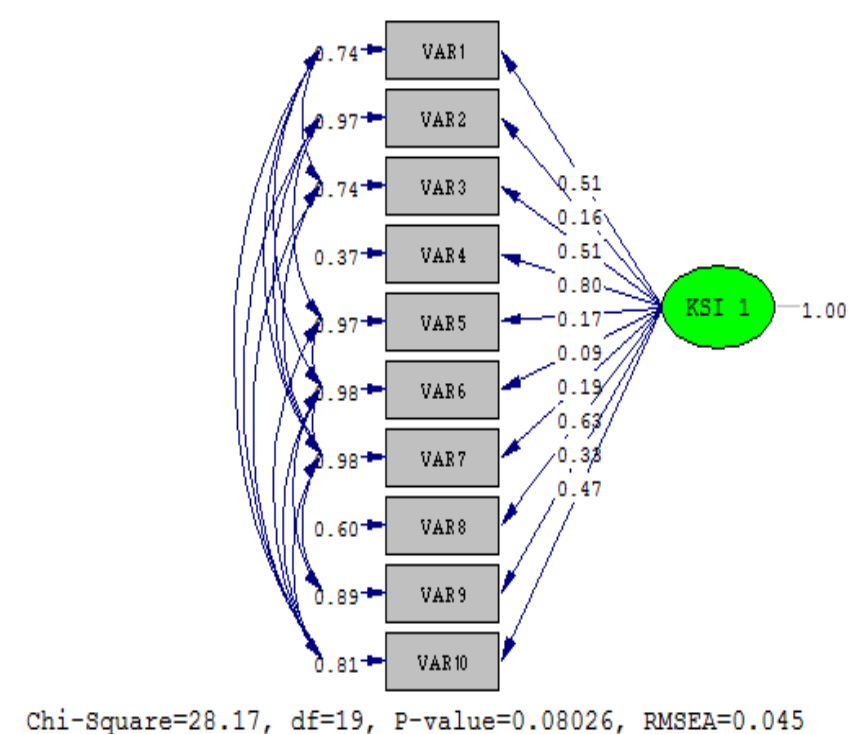

Gambar 14. Model FIT Dimensi 5 Uji coba 2

Berdasarkan Gambar 14 tersebut, terlihat bahwa nilai chi square sebesar $28,17, \mathrm{df}=19$ ( $p>$ $0,05)$. Dengan demikian dimensi 5 dinyatakan memiliki model unidimensional yang fit. Selanjutnya penulis memaparkan hasil uji validitas tiap item, hasilnya seperti terlihat pada Tabel 21 berikut ini:

Tabel 2I. Koefisien Muatan Faktor Item Dimensi 5

\begin{tabular}{|c|c|c|c|c|}
\hline Item & Koefisien & $\begin{array}{c}\text { Std. } \\
\text { Error }\end{array}$ & $\begin{array}{c}\text { Nilai } \\
\mathbf{t}\end{array}$ & Keterangan \\
\hline Item 38 & 0,5 I & 0,07 & $7, I 6$ & Valid \\
\hline Item 39 & 0,16 & 0,07 & 2,27 & Valid \\
\hline Item 40 & 0,5 I & 0,07 & 7,20 & Valid \\
\hline Item 4I & 0,8 & 0,07 & 12,88 & Valid \\
\hline Item 42 & 0,17 & 0,07 & 2,33 & Valid \\
\hline Item 43 & 0,09 & 0,07 & I,27 & Tidak Valid \\
\hline Item 44 & 0,19 & 0,07 & $2,5 I$ & Valid \\
\hline Item 45 & 0,63 & 0,06 & 9,95 & Valid \\
\hline Item 46 & 0,33 & 0,07 & $4,8 I$ & Valid \\
\hline Item 47 & 0,47 & 0,07 & 6,39 & Valid \\
\hline
\end{tabular}

Dari Tabel 21 tersebut, terlihat hanya ada I item yang dinyatakan tidak valid, yaitu: item 43 . Oleh karena itu, item 43 akan di drop jika ada analisis lebih lanjut pada penelitian ini.

\section{Dimensi 6}

Dimensi 6 memiliki sejumlah 10 item. hasil awal analisis CFA yang penulis peroleh, yaitu: nilai chi square sebesar 5|4,94, df=35 ( $<<0,05)$.
Dengan demikian, model dimensi 6 dinyatakan tidak fit. Oleh karena itu, penulis melakukan modifikasi pada model tersebut sehingga diperoleh hasil seperti yang terlihat pada Gambar I 5 berikut ini:

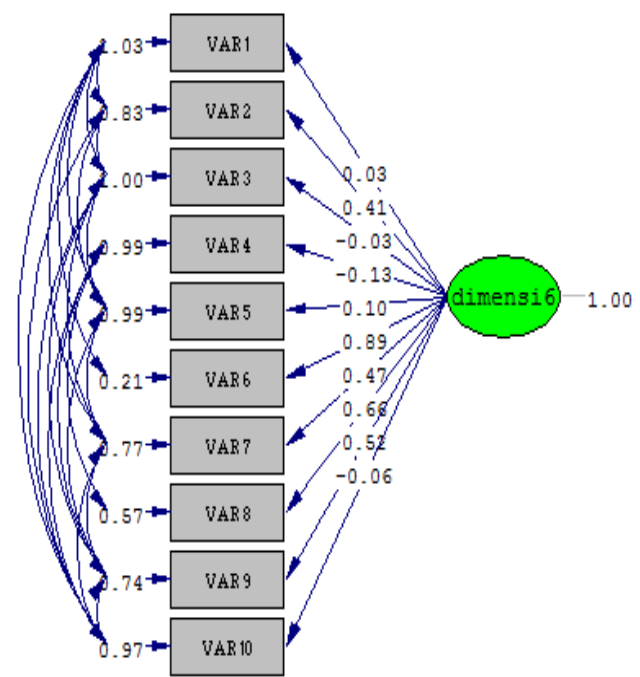

Chi-Square=18.80, df=14, P-value=0.17259, RMSEA=0.038

Gambar 15. Model FIT Dimensi 6 Uji coba 2

Berdasarkan Gambar 15 tersebut, terlihat bahwa nilai chi square sebesar $18,8, d f=\mid 4(p>$ $0,05)$. Dengan demikian, dimensi 6 dinyatakan fit. Selanjutnya penulis memaparkan tentang hasil uji validitas per item, seperti terlihat pada Tabel 22 berikut ini:

Tabel 22. Koefisien Muatan Faktor Item Dimensi 6

\begin{tabular}{|l|l|l|l|l|}
\hline Item & Koefisien & $\begin{array}{l}\text { Std. } \\
\text { Error }\end{array}$ & Nilai t & Keterangan \\
\hline Item 48 & 0,03 & 0,08 & 0,37 & Tidak Valid \\
\hline Item 49 & 0,41 & 0,07 & 6.08 & Valid \\
\hline Item 50 & $-0,03$ & 0,07 & $-0,48$ & Tidak Valid \\
\hline Item 5 I & $-0,13$ & 0,07 & $-2,00$ & Tidak Valid \\
\hline Item 52 & 0,10 & 0,07 & 1,37 & Tidak Valid \\
\hline Item 53 & 0,89 & 0,06 & 14,59 & Valid \\
\hline Item 54 & 0,47 & 0,07 & $7, I I$ & Valid \\
\hline Item 55 & 0,66 & 0,06 & 10,60 & Valid \\
\hline Item 56 & 0,52 & 0,06 & 8,07 & Valid \\
\hline Item 57 & $-0,06$ & 0,07 & $-0,91$ & Tidak Valid \\
\hline
\end{tabular}

Berdasarkan Tabel 22 tersebut, item yang dinyatakan tidak valid ialah item 48, 50, 5I, 52, dan 57. Sedangkan sisa item lainnya dinyatakan valid. Dengan demikian, item yang tidak valid 
tidak akan digunakan pada saat melakukan analisis lebih lanjut terhadap penelitian ini.

\section{d. Hasil penghitungan koefisien reliabilitas}

Tabel 23. Konstruk reliabilitas uji coba kedua

\begin{tabular}{|c|c|c|c|c|}
\hline Loading & Loading $^{2}$ & Error & $\begin{array}{c}\text { Loading }^{2+} \\
\text { Error }\end{array}$ & CR \\
\hline 13,72 & 188,2384 & 3,34 & 191,5784 & 0,982566 \\
\hline
\end{tabular}

Tabel 24. Variance extracted uji coba kedua

\begin{tabular}{|c|c|c|c|}
\hline ELoading & Error & $\begin{array}{c}\text { ELoading } \\
\text { Error }\end{array}$ & VE \\
\hline 10,8264 & 3,34 & 14,1664 & 0,764231 \\
\hline
\end{tabular}

Hasil perhitungan menunjukkan bahwa construct reliability sebesar $0,9825(>0,70)$, dan variance extract 0,7642 $(>0,5)$, dengan demikian dapat disimpulkan bahwa reliabilitas pada konstruk telah terpenuhi. Makin besar nilai ini, menunjukkan bahwa indikator-indikator penyusun bagi suatu peubah laten merupakan indikatorindikator yang handal dalam mengukur peubah laten tersebut. Nilai kehandalan konstruk yang disarankan adalah lebih besar dari 0,7. Sedangkan ukuran kelayakan variance extracted yang disarankan adalah lebih besar dari 0,5 .

\section{Kesimpulan dan Rekomendasi}

Berdasarkan penghitungan dan pembahasan sebagaimana diuraikan sebelumnya, maka penelitian pengembangan instrumen kemampuan inkuiri ilmiah siswa SMP pada mata pelajaran Biologi, dari hasil validasi pakar (panelis) secara kuantitatif dengan menghitung nilai CVR maka 57 (lima puluh tujuh) instrumen dinyatakan sesuai dan sangat sesuai. Hasil pengujian validitas empirik tahap pertama dan reliabilitas, pada dimensi I yang terdiri dari 9 soal, seluruhnya valid, pada dimensi 2 yang terdiri dari 8 soal, 6 soal valid dan 2 soal lainnya didrop, pada dimensi 3 yang terdiri dari 10 soal, 9 soal valid dan I soal lainnya didrop, pada dimensi 4 yang terdiri dari 10 soal, seluruhnya valid, pada dimensi 5 yang terdiri dari 10 soal, seluruhnya valid, pada dimensi 6 yang terdiri dari 10 soal, seluruhnya valid. Hasil perhitungan menunjukkan bahwa construct reliability sebesar 0,9958 $(>0,70)$, dan variance extract 0,8339 (> 0,5), dengan demikian dapat disimpulkan bahwa reliabilitas pada konstruk telah terpenuhi. Makin besar nilai ini, menunjukkan bahwa indikator-indikator penyusun bagi suatu peubah laten merupakan indikator-indikator yang handal dalam mengukur peubah laten tersebut. Nilai kehandalan konstruk yang disarankan adalah lebih besar dari 0,7. Sedangkan ukuran kelayakan variance extracted yang disarankan adalah lebih besar dari 0,5.

Hasil pengujian validitas empirik tahap kedua dan reliabilitas, pada dimensi I yang terdiri dari 9 soal, seluruhnya valid, pada dimensi 2 yang terdiri dari 6 soal, seluruhnya valid, pada dimensi 3 yang terdiri dari 9 soal, seluruhnya valid, pada dimensi 4 yang terdiri dari 10 soal, seluruhnya valid, pada dimensi 5 yang terdiri dari 10 soal, seluruhnya valid, pada dimensi 6 yang terdiri dari 10 soal, seluruhnya valid. Hasil perhitungan menunjukkan bahwa construct reliability sebesar $0,9961$ ( $>0,70)$, dan variance extract 0,8426 (> $0,5)$, dengan demikian dapat disimpulkan bahwa reliabilitas pada konstruk telah terpenuhi.

Dari 54 item setelah dianalisis dengan CFA pada uji coba kedua, ada 28 item yang valid artinya tidak terdapat perbedaan antara model teoretis unidimensional dengan model empiris. Pada dimensi I yang terdiri dari 9 soal, 4 soal valid, dan 5 soal didrop. Pada dimensi 2 yang terdiri dari 6 soal seluruhnya didrop. Pada dimensi 3 yang terdiri dari 9 soal, 2 soal valid dan 7 soal lainnya didrop. Pada dimensi 4 yang terdiri dari 10 soal, 8 soal valid, dan 2 soal didrop. Pada dimensi 5 yang terdiri dari 10 soal, 9 soal valid, dan I soal didrop. Pada dimensi 6 yang terdiri dari 10 soal, 5 soal valid, dan 5 soal didrop. Hasil penghitungan koefisien reliabilitas pada uji coba kedua $r=0,9825$ dengan koefisien reliabilitas > 0,70 , maka tes memiliki tingkat reliabilitas yang tinggi.

Hasil validitas empirik tahap pertama dan kedua uji coba pertama dari 57 soal ada 54 soal yang valid, 3 soal didrop. Hasil validitas empirik uji coba kedua dari 54 soal ada 28 soal yang valid, 26 soal didrop. Hasil akhir penelitian pengembangan instrumen kemampuan inkuiri ilmiah siswa SMP pada mata pelajaran Biologi adalah dihasilkannya 28 soal yang dapat digunakan untuk mendeteksi kemampuan inkuiri ilmiah siswa SMP pada mata pelajaran Biologi. 
Berdasarkan hasil penelitian yang telah disimpulkan tersebut dan dalam upaya mengembangkan instrumen kemampuan inkuiri ilmiah siswa SMP pada mata pelajaran Biologi, direkomendasikan hal-hal sebagai berikut:

I. Dalam mengembangkan instrumen kemampuan inkuiri ilmiah siswa SMP sebaiknya lebih banyak lagi dimensi yang digunakan, sehingga indikator lebih bervariasi dan lebih banyak soal-soal yang dapat digunakan untuk mendeteksi kemampuan inkuiri ilmiah siswa.

2. Kepada para pemegang kebijakan dalam pendidikan direkomendasikan melakukan pengembangan-pengembangan instrumen beberapa kemampuan siswa, melakukan pemberdayaan tenaga-tenaga kependidikan yang potensial dan memanfaatkan sumber daya pendidikan lainnya.

3. Dengan adanya beberapa keterbatasan dalam penelitian ini, kepada peneliti lain diharapkan untuk mengadakan penelitian sejenis lebih lanjut dengan mengambil wilayah penelitian yang lebih luas, sampel yang lebih banyak dan menggunakan analisis data yang berbeda, menggunakan mata pelajaran yang lebih banyak lagi, juga melakukan penelitian pada tingkat pendidikan di bawahnya atau tingkat pendidikan yang lebih tinggi seperti pada siswa SMA atau Universitas, sehingga dapat ditemukan hasil yang lebih optimal dan dapat digeneralisasikan pada wilayah yang lebih luas.

4. Untuk mendeteksi kemampuan inkuiri ilmiah siswa dapat dilakukan penelitian lanjutan, tentang interval skor yang didapat seorang siswa sehingga siswa dikategorikan memiliki kemampuan inkuiri ilmiah kurang, sedang, dan tinggi.

\section{DAFTAR PUSTAKA}

Djaali, dan Pudji Muljono. Pengukuran dalam Bidang Pendidikan. Jakarta: Grasindo PT Gramedia Widiasarana Indonesia, 2008.

Eichelberger, R. Tony. Disciplined Inquiry: Understanding and doing Educational Research. New York: Longman Inc., 1989.
Harrington, Donna. Confirmatory Factor Analysis. New York: Oxford University Press, 2009.

Marzano, Robert J., dan John S. Kendall. The New Taxonomy of Educational Objective. California: Corwin Press, 2007. 